\title{
THE IMPACT OF WARMIA AND MASURIA LOCAL AUTHORITIES ON ENTREPRENEURSHIP DEVELOPMENT IN THE BUSINESS LOCATION FACTORS CONTEXT
}

\author{
Renata Marks-Bielska, Ph.D., Associate Professor ${ }^{1}$ \\ Izabela Serocka, $\mathrm{MA}^{2}$ \\ University of Warmia and Mazury in Olsztyn, Faculty of Economics \\ M. Oczapowskiego 4, 10-719 Olsztyn, Poland \\ 1e-mail:renatam@uwm.edu.pl \\ ${ }^{2}$ e-mail: izabela.serocka@uwm.edu.pl
}

Received 11 November 2017, Accepted 26 March 2018

\begin{abstract}
Local authorities are a very important institution having a direct or indirect impact on attracting investors who significantly contribute to the entrepreneurship development at local and regional level. The main objective of the research was to evaluate the impact on entrepreneurship development in the business location factors context by Warmia and Masuria local authorities representing different types of communes. The results obtained allowed to determine in which type of commune, Warmia and Masuria local authorities actively supported the entrepreneurship development in their activity area and, among others, to indicate which location factors were less important, and which were gaining in importance in the business location process. Based on the results obtained, it can be concluded that local authorities of urban and urban-rural communes feel a stronger need to improve entrepreneurship development in their area. The research also showed that the location factors hierarchy shaped in a slightly different way depending on the perception of the local authorities representing different types of communes.
\end{abstract}

Keywords: economic development, local development, local authorities, location factors, entrepreneurship.

JEL classification: F63, H70, H72, R30, L26 


\section{Introduction}

Economic development is a process that improves the living conditions of a society. Despite the steady progress of economic knowledge, we failed to build a strong development theory which would convincingly explain the sources of economic dynamism, development mechanisms and their conditions in relation to most countries. In seeking of the most important development sources by economists, their attention was shifting from physical or resource factors (land, other natural resources, labour force) to the factors which are more difficult to measure. These researchers concluded that the most important and inexhaustible sources of development are in man and his relationships with other people. Therefore, economic development is the effect of an extremely complex combination of social, cultural, production, and ecological factors. The bonds, interactions, and impacts that arise in the economic development process are very complex (Wilkin, 2005).

Broadly understood institutions, as well as the institutional environment, have long been the main point of interest of economists as one of the basic economic growth and development factors. The different institutional systems are often accompanied by a similar growth rate, which in turn forces the given system solutions. Institutional systems are directly associated with the institutional potential which constitute opportunities and motivations to deal effectively with economic purposes by individual entities (creating the right environment and application of stimulants to take action tools) (Chmielak, 2002; Staniek, 2014).

The business environment institutions (BEIs) (including local authorities) are essential for shaping relations between these institutions and foreign companies. The quality, nature, and efficiency of individual relations translate into the regional development. This is particularly important for those administrative units whose competitive advantage and the degree of urbanization are inferior. Owing to good cooperation between BEIs staff and investors, the quality of life among local and regional communities improves, the spirit of enterprise is encouraged, and a positive image of the region is strengthened. On the other hand, the weaker the collaboration between BEIs and business companies, the slower the local development, to the point of being negligible (Górzyński, Koć, Pander, 2006; Stachowiak, 2007).

The incentives affecting the choice of investment locations by entrepreneurs are well known but local authorities do not have an impact on all investment stimulating factors, e.g. on geographical conditions or on the local market. However, they may be significantly influenced by, for example, the condition of the technical infrastructure, the technical condition of the office and the production buildings intended for a possible investment, the quality and efficiency 
of the service provided by officials, the attitude of the local authorities and community to the entrepreneurs, transport accessibility to the investment areas, creation of workforce professional competence through access to learning, assistance in communication between investors and business environment institutions, tax incentives at a local level, and so on.

These factors depend on different conditions and they are characterized by variability over time (Czaplewski, 2005). The region's investment attractiveness is determined by a set of characteristics that encourage or discourage investors from investing in a given area. This attractiveness in particular regions is the utility of investment place which determines this region advantage over others (Kopczuk, 2005).

Local authorities are a very important institution having a direct or indirect impact on attracting investors who significantly contribute to the entrepreneurship development at a local and regional level. This impact can be understood as a different kind of local authorities' activity that aims to create new work places and the best conditions for living in a given local and regional environment. The basic task of local authorities is to provide communal roads and streets, bridges, squares and road traffic organization, spatial order, environmental and natural protection, public order and security for citizens, commune development, cooperation with nongovernmental organizations, public education, and the dissemination of culture, health care, and tourism (Miszczuk, Miszczuk, Żuk, 2007; Marks-Bielska, Babuchowska, 2012).

Expectations of business people, often stimulated by a change in the economic and political system, progress of sciences and technology, social and economic progress, globalization, etc., are constantly changing. This means that the local authorities must adjust their services, within the legal framework, to a wide range of expectations. Entrepreneurship requires stimulation in conditions conducive to the emergence of new business initiatives. This in turn leads to the actual implementation and adoption of new business initiatives. Through an appropriate and skillful re-shaping of the conditions for running a business, local authorities can contribute to the acquisition of new investments or expansion of the existing companies.

\section{Methodology}

The main objective of the research was to evaluate the impact of Warmia and Masuria local authorities representing different types of communes on entrepreneurship development.

The entrepreneurship development at the local level is a key factor in the socio-economic development of the region. Investors looking for a place to conduct their business analyse the investment attractiveness in a regional and local dimension. The research scope was related 
to the importance of perception of actions and location factors by Warmia and Masuria local authorities, influencing enterprises' investment decisions.

Direct surveys were carried out using questionnaires distributed among Warmia and Masuria local authorities in the fourth quarter of 2015. The questionnaires were sent by post to all 116 communes. As a result, 70 correctly completed questionnaires were received. This guaranteed a high level of returned questionnaires $(60.3 \%)$. This is a basis for the recognition that the results obtained can be generalized for the entire community of Warmian-Masurian Voivodeship.

In order to interpret the collected data, simple statistical methods and the validity index used by Kola et al. (2005) were applied. This index was calculated according to the formula:

where:

$$
W=\frac{\sum_{i=1}^{k} n_{i} w_{i}}{k \cdot N},
$$

$$
\begin{aligned}
& \begin{array}{l}
W \text { - validity index, } \\
i
\end{array} \text { - evaluation index, } \\
& n_{i}-\text { number of indications of a given factor in the } i \text {-th place, } \\
& w_{i}-\text { evaluation corresponding to the location of the } i \text { factor (the indicator takes values } \\
& \quad \text { from } 0 \text { to } 1 \text {; if its value is higher, the location factor has been more important), } \\
& k-\text { maximum rating on a scale from } 1 \text { to } k, \\
& N-\text { the number of respondents who answered the question. }
\end{aligned}
$$

\section{Research results}

The local authorities' need for entrepreneurship development in individual communes is very important because without them all actions related to acquiring or expanding investments would not be applied. The research results showed that the vast majority of the surveyed Warmia and Masuria local authorities (regardless of the commune type) concluded that the entrepreneurship development level in their commune was lower than its needs (Figure 1). The remaining group of respondents considered that this level was adequate to the commune's needs.

It is interesting to note that the largest group of respondents $(25.0 \%)$ who recognized that the entrepreneurship development level in their commune was adequate to its needs, was those representing the rural communes. Analogously, the smallest group of the same respondents stated that the entrepreneurship development level was lower than the commune's needs $(75.0 \%)$. 


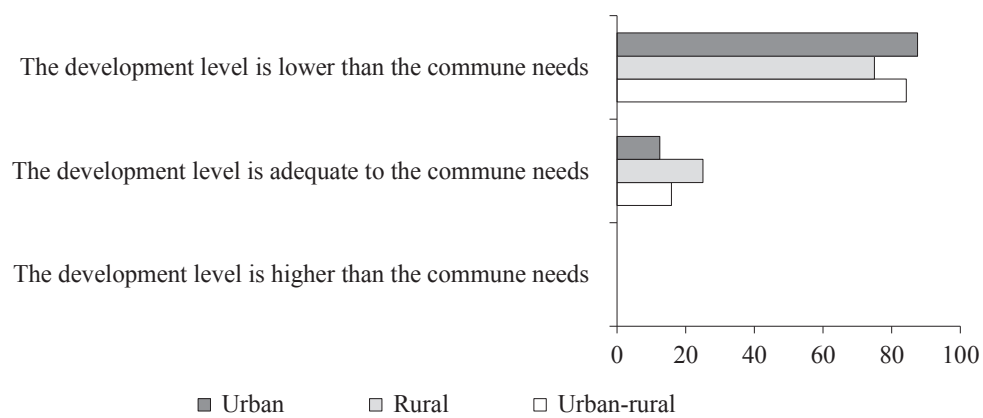

Figure 1. The entrepreneurship development level in the particular types of communes in relation to their needs $(\%)$

Source: author's own survey research.

This may mean that every fourth respondent from a rural commune either had understated the commune's needs on entrepreneurial development, or its development level is indeed adequate to the needs. On the other hand, the local authorities of the vast majority of communes (84.2\%) considered that the level of entrepreneurship development was lower than the commune's needs. Based on the research results, it can be concluded that the local authorities of urban and urban-rural communes feel a stronger need to improve the entrepreneurship development in their commune.

The investment opportunities offered by the commune are intended to induce potential investors to start a business in a specific location. Constantly progressing globalization and growing competition between the regions to attract investors (both domestic and foreign) lead to the entrepreneurship development level not always being adequate to the investment attractiveness of individual communes. A small group of all surveyed local authorities considered that the entrepreneurship development level was higher than the commune's investment opportunities and they were representatives of the rural communes (10.0\%) (Figure 2). Perhaps this was due to the appearance of an investor who, unlike the local authorities of these communes, found that the investment opportunities in the area were sufficient to start a business.

On the other hand, $33.3 \%$ of the urban communes authorities indicated, that the development level was adequate to investments opportunities and it was the largest share among all in this group. This result may be related to the fact that local authorities have relatively better investment opportunities. The entrepreneurship development level was lower than offered investment opportunities in most surveyed communes, and the largest group of it was urbanrural communes $-77.8 \%$. 


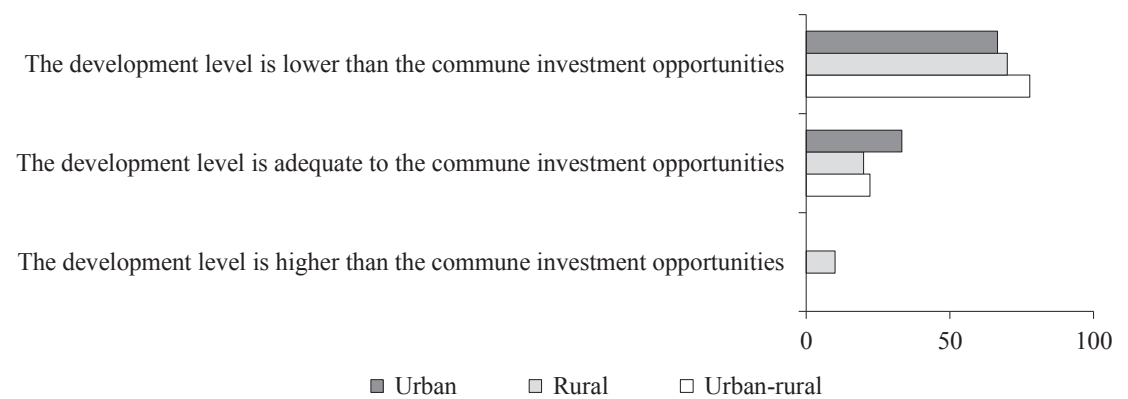

Figure 2. The entrepreneurship development level in the particular types of communes in relation to investments needs (\%)

Source: author's own survey research.

Given the fact that the country's socio-economic development depends primarily on the entrepreneurship development level at the local and regional level, it can be stated that the research results on this development (regardless of the commune's type) are concerning. If the entrepreneurship development level is lower than the commune's needs, it can be expected that in the short or long term, the commune will have to deal with such problems as an increasing unemployment rate or emigration which may in turn lower the quality of the local society's life or lead to a demographic decline.

The research was also aimed at determining how local authorities perceive the commune's investment attractiveness (Figure 3).

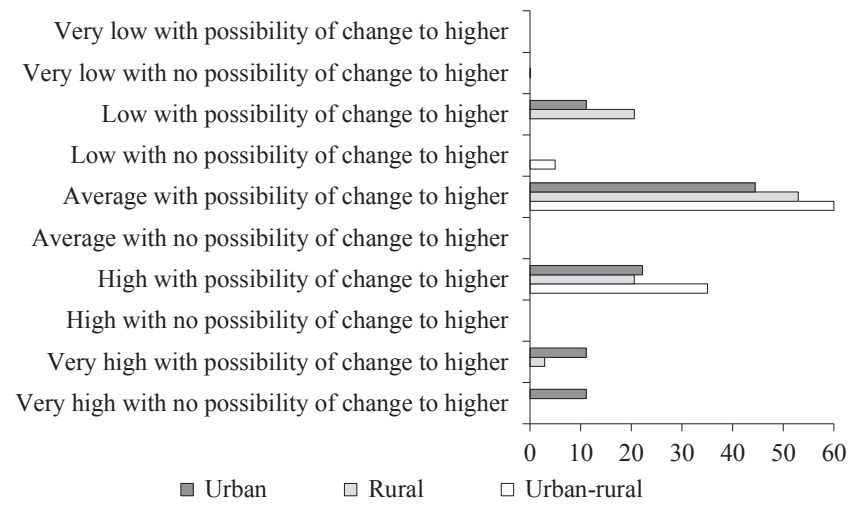

Figure 3. Investment attractiveness in the particular types of communes according to the local authorities' opinion (\%)

Source: author's own survey research. 
The most frequent response in regards to investment attractiveness was 'average with possibility of change to higher' (of which the majority of the respondents were urban-rural local authorities $-60.0 \%$ ). 'High investment attractiveness with possibility of further improvement' was also indicated by the largest number of local authorities representing urban-rural communes (35.0\%). A positive aspect of the investment attractiveness research is the fact that a very small proportion of the respondents stated that there is no way to improve the commune's investment attractiveness regardless of its level. Very high attractiveness without the possibility of further improvement was indicated by $11.1 \%$ of urban communes. The same level but with the possibility of further improvement was indicated by $11.1 \%$ of urban communes and by only $2.9 \%$ of rural communes. A very low and low level were indicated by the local authorities mainly from rural communes $(20.6 \%)$, which could have been expected given the lower levels of urbanisation.

The entrepreneurship development within individual communes is not only determined by the investment attractiveness, but also by the local authorities' awareness of the significance of this kind of development. Taking a variety of actions in this direction often results in the acquisition of new investments or the enlargement of the existing ones. Therefore, the respondents were also asked to identify whether they were undertaking business support activities.

Supporting entrepreneurship is a priority for half of the surveyed local authorities from urban communes, and for almost half of those from urban-rural communes $(45.8 \%)$. Only every 5th respondent from rural communes recognized the supporting of entrepreneurship as a commune's priority. On the other hand, the limited number of actions due to limited or stagnant financial resources were indicated by $36.0 \%$ of rural commune authorities and $25.0 \%$ of urbanrural ones. It can be considered that the Warmia and Masuria local authorities, mainly from urban and partly from urban-rural communes, are more aware of the importance of supporting entrepreneurship, and they undertake numerous activities for this purpose. One positive outcome of the research conducted is the plan to increase the support of entrepreneurship in the coming years $-25.0 \%$ of the local authorities in rural communes, $20.0 \%$ in urban, and $13.0 \%$ in urbanrural areas (Figure 4).

On the other hand, the respondents' answers about the real impact of the local authorities' activity on enterprises location are quite different depending on the type of commune (Figure 5).

A considerable impact was indicated by $30.1 \%$ of the respondents from urban communes, $20.8 \%$ from urban-rural areas, and only $11.1 \%$ from rural ones. In turn, the average influence was indicated by $70.0 \%$ of urban communes, and by $58.3 \%$ of urban-rural and rural ones. $19.4 \%$ of the respondents from rural communes and $16.7 \%$ of those from from urban-rural ones indicated a low impact. $11.1 \%$ of the respondents from rural communes found that local authorities did 


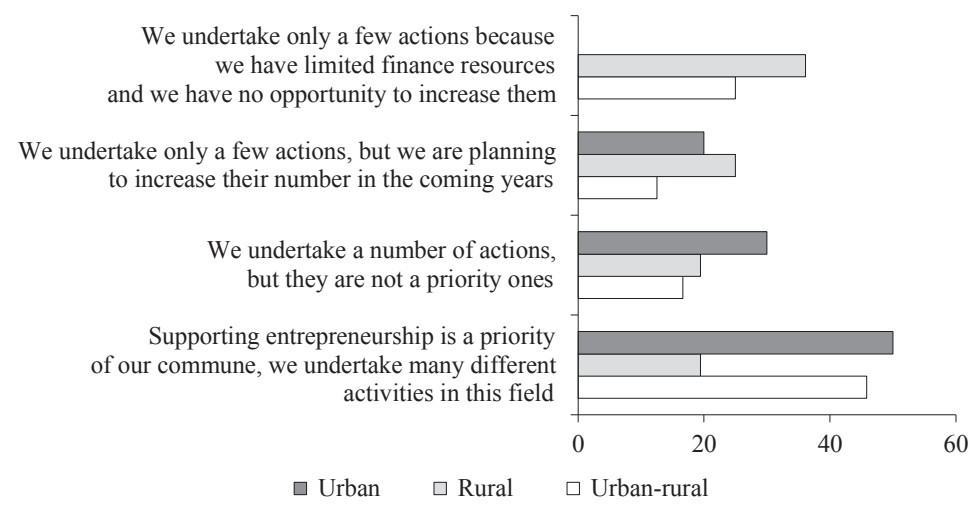

Figure 4. Local authorities' activity depending on the particular types of communes in supporting entrepreneurship (\%)

Source: author's own survey research.

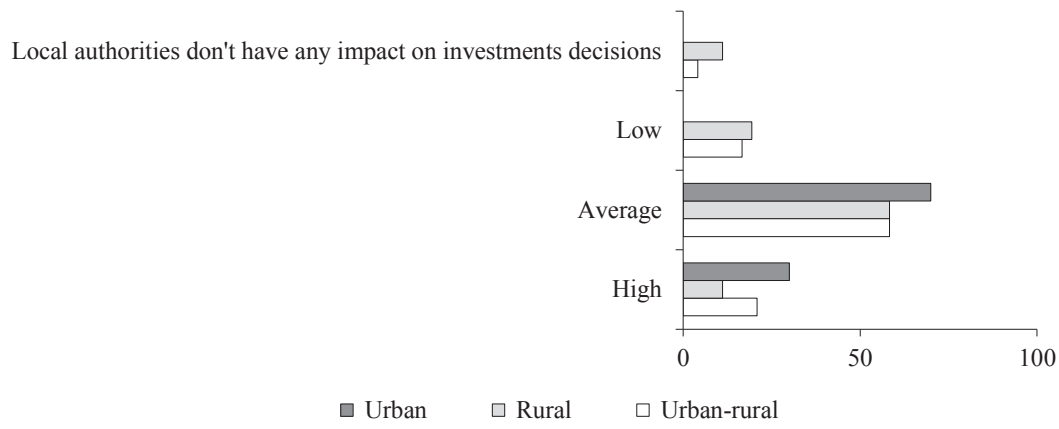

Figure 5. The real impact of the local authorities' activity on enterprises location depending on the type of commune $(\%)$

Source: author's own survey research.

not have an influence on the enterprise investment decisions. A similar opinion was recorded by $4.2 \%$ of the respondents from urban-rural communes. The research results showed that the largest real impact on the business start-up and operation is found in urban communes. This may be due to the fact that these communes have more financial resources and subsequnetly are better able to develop the investment areas belonging to the commune. In addition, an employee responsible for the contact with investors is often employed in urban communes, which is often not the case in rural and urban-rural communes due to the lack of financial resources for this purpose. In regards to the results of the research, we should consider the reasons for the low impact of the local authorities from rural and urban-rural communes on the enterprise investment 
decisions. Is it due to a weak local government activity, low investment attractiveness, or the lack of financial funds?

The local authorities' decisions and needs dictate whether they go outside their competence area and carry out optional tasks such as those related to the entrepreneurship development improvement at the local level. The received response structure indicates a different approach to implementing optional tasks by the local authorities depending on its type (Figure 6).

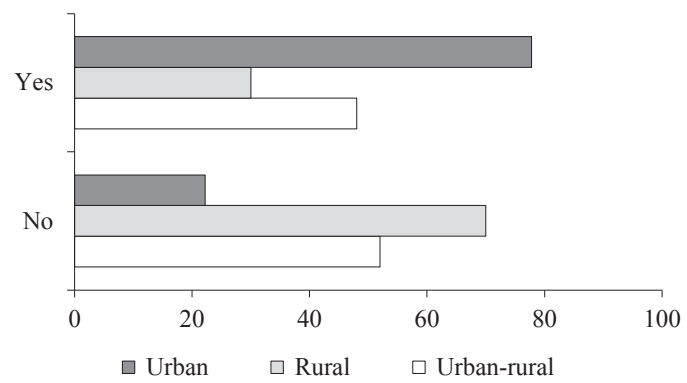

Figure 6. Do the local authorities of the particular types of communes perform optional tasks? (\%) Source: author's own survey research.

Among the surveyed local authorities from Warmian and Masurian Voivodeship, $70.0 \%$ of rural communes, $52.0 \%$ of urban-rural areas, and only $22.2 \%$ of urban areas did not implement optional tasks. Conversely, the largest part of the communes which implemented such tasks were urban communes $(77.8 \%)$, which in recent years have carried out the following tasks: land development in a Special Economic Zone, creation of a business incubator, exemption from property tax for the purchase of the land for investment, development of economic diagnosis, involving businesses in social issues, cooperation with business environment institutions and the National Chamber of Tax Advisers, and active entrepreneurship support activities conducted in cooperation with the Marshal Offices. In turn, urban-rural local authorities (43.5\% of them) focused on the implementation of optional tasks such as: exemption from property tax for newly established companies, help with sourcing the correct documentation, establishment of the Economic Council, promotion of investment areas, creation of the business zone, organization of meetings with potential investors to develop positive relationships, participation in business fairs and conferences, adapting local laws to create new enterprises, individually tailored approaches to investors and their challenges, and administration assistance. Only every third of the rural communes performed optional tasks in recent years and they relied on: promotion of investment areas, investors support, use of tax reliefs, technical infrastructure improvement, 
inviting investor support institutions, organization of residents and investor meetings, participation in conferences, training, establishing networks with other countries, adopting a tax credit for new investments depending on the number of employed people from a commune territory, and planning to create an economic council with advisors from within the business community (entrepreneur as an advisor).

Local authorities may influence business investment decisions, as documented in numerous scientific publications. The research conducted allowed to determine which activities concerning the various types of infrastructure have the greatest influence on the business location according to the Warmia and Masuria local authorities. The respondents from urban communes indicated the following actions (Table 1): modernization of public lighting, shaping of safe public spaces, construction or modernization of sewage treatment plants, improving quality and service in commune offices, a favourable attitude of officials to entrepreneurs, a more cooperative relationship between officials and entrepreneurs, assistance in establishing contacts with contractors, assistance in acquiring funding from the EU and Polish government, and the assistance in introducing new technologies (100.0\%). On the other hand, the representatives of rural and urban-rural communes considered that the following had the greatest influence:

Table 1. Activities related to technical and institutional infrastructure that have the greatest impact on enterprises location decisions, according to the local authorities of urban, rural and urban-rural communes from Warmian and Masurian Voivodeship

\begin{tabular}{|l|c|c|c|}
\hline \multicolumn{1}{|c|}{ Specification } & \multicolumn{3}{c|}{ Commune type } \\
\cline { 2 - 4 } & urban & rural & urban-rural \\
\hline Improving the public transport & 80.0 & 77.3 & 73.7 \\
\hline Construction/modernization of fiber optic network & 80.0 & 79.2 & 76.5 \\
\hline Developing an investment area & 90.0 & 67.9 & 85.0 \\
\hline Modernization of public lighting, shaping of safe public spaces & 100.0 & 76.5 & 81.0 \\
\hline Construction/modernization of sewage treatment plants & 100.0 & 90.3 & 85.0 \\
\hline Improving quality and service in commune's offices & 100.0 & 90.6 & 87.5 \\
\hline $\begin{array}{l}\text { Favourable attitude of officials to entrepreneurs, a more cooperative } \\
\text { relationship between officials and entrepreneurs }\end{array}$ & 100.0 & 93.9 & 91.3 \\
\hline Assistance in contacts with contractors & 100.0 & 60.7 & 57.9 \\
\hline Assistance in raising funds from the EU & 100.0 & 66.7 & 77.3 \\
\hline Assistance in raising funds from the government & 100.0 & 61.5 & 65.0 \\
\hline Assistance in introducing new technologies & 100.0 & 47.6 & 38.9 \\
\hline Assistance in promoting companies' products from a commune territory & 88.9 & 62.5 & 81.0 \\
\hline $\begin{array}{l}\text { Promotional actions of the commune in order to obtain new investments } \\
\text { (promotional brochures, participation in business fairs, conferences) }\end{array}$ & 90.0 & 46.4 & 73.9 \\
\hline Lowering local taxes & 70.0 & 64.3 & 70.0 \\
\hline Improving the workforce skills by running/financing training, courses & 87.5 & 66.7 & 60.0 \\
\hline Assistance in the recruitment and training of employees & 71.4 & 60.0 & 57.9 \\
\hline
\end{tabular}

Source: author's own survey research. 
favourable attitude of officials to entrepreneurs, improving quality and service in commune's office, construction or modernization of sewage treatment plants, and developing investment area.

Business investment decisions are also influenced by the activities related to social services, cultural services, etc., because the shaping of favourable living conditions strengthens the size and quality of labour resources. The most important activity, regardless of the commune's type, was the active commune development in intellectual and cultural terms $(90.0 \%$ and more responses). The other activities and their order of importance listed in Table 2 are different for each type of commune. The least important activity in the opinion of the local authorities was assistance and support in the individual building (66.7\%), whereas according to the authorities of rural and urban-rural communes, social housing was of the least importance (in sequence $18.8,50.5 \%)$.

Table 2. Activities related to the social climate which have the greatest influence on the enterprises location decisions, according to the local authorities' opinions of urban, rural, and urban-rural commune types from Warmian and Masurian Voivodship

\begin{tabular}{|l|c|c|c|}
\hline \multicolumn{1}{|c|}{ Specification } & \multicolumn{2}{c|}{ Commune type } \\
\cline { 2 - 4 } & urban & rural & urban-rural \\
\hline $\begin{array}{l}\text { Active commune's development of intellectual and cultural terms (taking care } \\
\text { of good conditions for spending free time and recreation such as sports } \\
\text { and recreation facilities, public green areas) }\end{array}$ & 90.0 & 91.2 & 95.8 \\
\hline $\begin{array}{l}\text { Elaboration and implementation of the commune's strategy for solving social } \\
\text { problems (creating social assistance programs, preventing and solving alcohol } \\
\text { and other problems, cash benefits) }\end{array}$ & 70.0 & 80.6 & 70.8 \\
\hline Assistance and support in the individual housing & 66.7 & 35.3 & 70.6 \\
\hline Social housing & 70.0 & 18.8 & 50.0 \\
\hline Maintenance, renewal, and modernization of commune's housing stock & 80.0 & 45.2 & 65.2 \\
\hline $\begin{array}{l}\text { Ensuring safety and hygienic learning conditions, providing material aid } \\
\text { of a social character }\end{array}$ & 80.0 & 66.7 & 72.7 \\
\hline
\end{tabular}

Source: author's own survey research.

Every entrepreneur who is looking for a place to conduct business, draws attention, among others, on how long it will take to start the investment. This is influenced by various local legal regulations, including those related to the commune's spatial policy and environmental protection. The local authorities from Warmian and Masurian Voivodeship unanimously recognized that the greatest influence to the business location was the active implementation of the commune's spatial policy, in particular, having an orderly legal status of the local land for sale (Table 3). 
Table 3. Activities related to spatial policy and environmental protection which have the greatest influence on business location decisions, according to the local authorities' opinions of the particular commune's types from Warmian and Masurian Voivodeship

\begin{tabular}{|l|c|c|c|}
\hline \multicolumn{1}{|c|}{ Specification } & \multicolumn{3}{c|}{ Commune type } \\
\cline { 2 - 4 } & urban & rural & urban-rural \\
\hline $\begin{array}{l}\text { Active commune participation in the local real estate market (sales, purchase, } \\
\text { lease, rent, donation) }\end{array}$ & 87.5 & 57.6 & 81.0 \\
\hline $\begin{array}{l}\text { Active implementation of the commune's spatial policy (e.g. having an orderly } \\
\text { legal status of the local land for sale) }\end{array}$ & 100.0 & 82.4 & 95.7 \\
\hline Availability of land, buildings, and office spaces & 77.8 & 48.0 & 84.2 \\
\hline Increasing the tourist attractiveness of a commune and its surroundings & 90.0 & 78.8 & 79.2 \\
\hline Exemption from property tax & 88.9 & 53.6 & 64.7 \\
\hline
\end{tabular}

Source: author's own survey research.

The local authorities perception of the importance of location is a very interesting subject of research according to a different commune's type. The research results showed that the hierarchy of location factors is slightly different depending on their perception by the local authorities representing different types of communes (Table 4). Taking into account three of the most important location factors according to the local authorities' opinions from urban communes, they were: the attitude of the officials to the entrepreneurs, the quality and efficiency of offices' service, and the active implementation of the commune's spatial policy $(100.0 \%$ for each factor). On the other hand, the most important location factors in opinion of the local authorities from rural communes were: the telecommunication infrastructure condition (71.4\%), the condition of water and sewage infrastructure $(68.6 \%)$, and the condition of the communication infrastructure (65.7\%). The local authorities of urban-rural communes indicated: the communication infrastructure condition, safety and hygiene education conditions, and the availability of commune's land, buildings, and various types of spaces ( $79.2 \%$ of each factor).

Table 4. The importance of location factors according to the local authorities' opinions from the particular commune's types in Warmian and Masurian Voivodeship and the location factors' validity index

\begin{tabular}{|c|c|c|c|c|}
\hline \multirow[b]{2}{*}{ Specification } & \multicolumn{3}{|c|}{ Commune type } & \multirow{2}{*}{$\begin{array}{c}\text { Location } \\
\text { factors' } \\
\text { validity index }\end{array}$} \\
\hline & urban & rural & urban-rural & \\
\hline 1 & 2 & 3 & 4 & 5 \\
\hline $\begin{array}{l}\text { The communication infrastructure condition (transport } \\
\text { and communication) }\end{array}$ & 90 & 65.7 & 79.2 & 0.70 \\
\hline The telecommunication infrastructure condition (Internet networks) & 70 & 71.4 & 66.7 & 0.69 \\
\hline Condition of water and sewage infrastructure & 90 & 68.6 & 75.0 & 0.73 \\
\hline
\end{tabular}




\begin{tabular}{|l|c|c|c|c|}
\hline \multicolumn{1}{|c|}{1} & 2 & 3 & 4 & 5 \\
\hline $\begin{array}{l}\text { Institutional infrastructure condition (activities of institutions } \\
\text { supporting the entrepreneurship development) }\end{array}$ & 70 & 37.1 & 33.3 & 0.37 \\
\hline The quality and efficiency of offices' service & 100 & 54.3 & 75.0 & 0.67 \\
\hline The attitude of the officials to the entrepreneurs & 100 & 60 & 66.7 & 0.67 \\
\hline Organization of social assistance & 50 & 17.1 & 20.8 & 0.14 \\
\hline $\begin{array}{l}\text { Schools, nurseries, kindergartens (safety and hygienic education } \\
\text { conditions) }\end{array}$ & 90 & 37.1 & 79.2 & 0.59 \\
\hline Quality of health care & 50 & 17.1 & 62.5 & 0.31 \\
\hline Conditions for spending free time and resting & 80 & 45.7 & 50.0 & 0.49 \\
\hline Commune housing policy & 60 & 5.7 & 8.7 & 0.03 \\
\hline Public order and safety & 60 & 31.4 & 66.7 & 0.46 \\
\hline Sanitary safety & 60 & 31.4 & 62.5 & 0.44 \\
\hline Natural environment condition & 66.7 & 29.4 & 62.5 & 0.46 \\
\hline Commune's spatial policy (active realization) & 100 & 58.8 & 75.0 & 0.70 \\
\hline $\begin{array}{l}\text { The availability of commune's land, buildings, office, production, } \\
\text { and warehouse spaces }\end{array}$ & 90 & 41.2 & 79.2 & 0.56 \\
\hline The cost of renting or buying land from communal property & 88.9 & 50 & 75.0 & 0.60 \\
\hline Rent or purchase of buildings from communal property & 88.9 & 38.2 & 70.8 & 0.53 \\
\hline The amount of taxes and local fees & 80 & 52.9 & 50.0 & 0.50 \\
\hline
\end{tabular}

Source: author's own survey research.

In the opinion of all the respondents (regardless of the type of commune), the factors that gained the most importance were: condition of water and sewage infrastructure (validity index 0.73), the communication infrastructure condition (transport and communication), and the active realization of commune's spatial policy ( 0.70 each). In turn, the smallest importance according to the validity index had such factors as: commune housing policy $(0.03)$, organization of social assistance (0.14), and the quality of health care (0.31).

The Warmia and Masuria local authorities' perception of the importance of location factors may be connected with a relatively low level of investment attractiveness for this voivodeship. The research results also reflect the experience acquired by the local authorities of the particular commune's types connected with the entrepreneurship development. It is important to consider whether the varied hierarchy of location factors is related only to the level of investment opportunities of the individual communes or it results from the lack of relevant knowledge about the entrepreneurs requirements. 


\section{Conclusions}

Societal living conditions are improved as a result of economic and entrepreneurship development. The local authorities' awareness of this kind of development is very important as without them the activities related to acquiring or expanding investments would not be applied. The research conducted showed that the Warmia and Masuria local authorities of urban and urban-rural communes felt a stronger need to improve the entrepreneurship development in their commune's territory.

The support of entrepreneurship was a priority for half of the surveyed local authorities from urban communes and for almost half of those from urban-rural communes (45.8\%). Only every 5th respondent from a rural commune recognized the supporting of entrepreneurship as a commune's priority. On the other hand, the limited number of actions due to limited financial resources and the lack of possibilities for their increase were indicated by $36.0 \%$ of rural commune authorities and $25.0 \%$ of urban-rural ones. It can be considered that the Warmia and Masuria local authorities mainly from urban and partly from urban-rural communes are more aware of the importance of supporting entrepreneurship and they undertake numerous activities for this purpose.

The research results showed that the largest real impact on business start-up and operation are within urban communes (100.0\% of medium and high impact). This may be due to the fact that these communes have more financial resources and are in way better able to develop the investment areas within the commune.

According to the validity index, the factors that gain the most importance were: condition of water and sewage infrastructure (0.73), the communication infrastructure condition (transport and communication), and active realization of commune's spatial policy (0.70 each).

The results obtained showed that the hierarchy of location factors is slightly different depending on their perception by local authorities representing different types of communes. The respondents representing urban communes indicated that the location was the most important factor, which was related to the quality of the services provided. On the other hand, the local authorities of rural and urban-rural communes were selected on these location factors, which are related to the condition of various types of infrastructure. This may be the effect of relatively lower technical infrastructure development in rural and urban-rural communes, or of the lack of relevant knowledge about the entrepreneurs' requirements. 


\section{References}

Chmielak, A. (2002). Instytucjonalne podstawy trwałości rozwoju gospodarczego. Białystok: Wyższa Szkoła Finansów i Zarządzania w Białymstoku.

Czaplewski, L. (2005). Działania samorządów lokalnych województwa kujawsko-pomorskiego na rzecz podniesienia atrakcyjności inwestycyjnej regionu w celu pozyskania bezpośrednich inwestycji zagranicznych. In: W. Karaszewski (ed.), Bezpośrednie inwestycje zagraniczne w podnoszeniu konkurencyjności polskiej gospodarki. Praca zbiorowa (pp. 165183). Toruń: Uniwersytet Mikołaja Kopernika.

Górzyński, M., Koć, P., Pander, W. (2006). Tworzenie związków kooperacyjnych między MSP oraz MSP i instytucjami otoczenia biznesu. Warszawa: Polska Agencja Rozwoju Przedsiębiorczości.

Kola, M., Kujawka, M., Kuzel, M., Piotrowska-Trybull, M., Studzińska, K. (2005). Metodyka badań. In: W. Karaszewski (ed.), Bezpośrednie inwestycje zagraniczne $w$ województwie kujawsko-pomorskim. Stan, znaczenie dla gospodarki województwa, stymulanty i destymulanty napływu (pp. 26-38). Toruń: Uniwersytet Mikołaja Kopernika.

Kopczuk, A. (2005). Atrakcyjność inwestycyjna gminy w ocenie samorządów lokalnych województwa podlaskiego. In: A. Kopczuk, M. Proniewski (eds.), Atrakcyjność inwestycyjna regionu (pp. 479-490). Białystok: Wyższa Szkoła Finansów i Zarządzania w Białymstoku.

Marks-Bielska, R., Babuchowska, K. (2012). Rola władz lokalnych we wspieraniu przedsiębiorczości gospodarczej. In: K. Jaremczuk (ed.), Przedsiębiorczość - natura atrybuty (pp. 367-387). Tarnobrzeg: PWSZ im. prof. S. Tarnowskiego w Tarnobrzegu, T. II.

Miszczuk, A., Miszczuk, M., Żuk, K. (2007). Gospodarka samorządu terytorialnego. Warszawa: Wydawnictwo Naukowe PWN.

Stachowiak, K. (2007). Instytucjonalne uwarunkowania bezpośrednich inwestycji zagranicznych w Polsce. Poznań: Wydawnictwo Naukowe Bogucki.

Staniek, Z. (2014). Instytucje i problemy ich mierzenia. In: S. Rudolf (ed.), Nowa ekonomia instytucjonalna wobec współczesnych problemów gospodarczych (pp. 51-80). Kielce: Wydawnictwo Wyższej Szkoły Ekonomii, Prawa i Nauk Medycznych: Kieleckie Towarzystwo Edukacji Ekonomicznej.

Wilkin, J. (2005). Instytucjonalne podstawy rozwoju gospodarczego. Zagadnienia Ekonomiczne. UWM. 